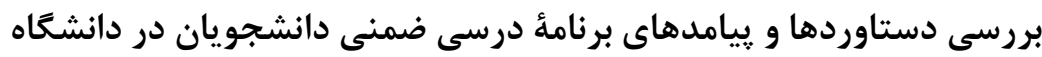

\title{
An Investigation into the Outcomes of Implicit Curriculum in Higher Education
}

M.Amini, .R.Marzughi (Ph.D)

M.Mazidi (Ph.D), J.Torkzade (Ph.D), M.Mohammadi (Ph.D)

Abstract: The research goal was to investigate the outcomes of implicit curriculum from university students' point of view.A purposeful sample of 15 professors and 20 students from shiraz university participated in the study. Data were collected through the research literature and by doing interviews with key experts and then the collected data analyzed by using the thematic network model. The set of 154 coded-common experiences were identified. Findings were classified into three major categories including: 1) basic concepts; 2) organizing themes; 3 ) inclusive themes. Results generally indicate that the main outcomes that students learned through the implicit curriculum are as follows: 1) authority; 2) discipline behaviors; 3 ) sense of comfort; 4) self- worth; 5) selfcontrol; 6) social solidarity; 7) valueoriented approach; 8) responsibility; 9) passing exams with the minimum of effort; 10) cheating ; 11) stereotyping; 12) gaining scientific spirit; 13) deep study, and 14) undeep study.

Key Words :Qualitative Research, Case Study, Thematic Network, Implicit Curriculum, Implicit Curriculum Outcomes.

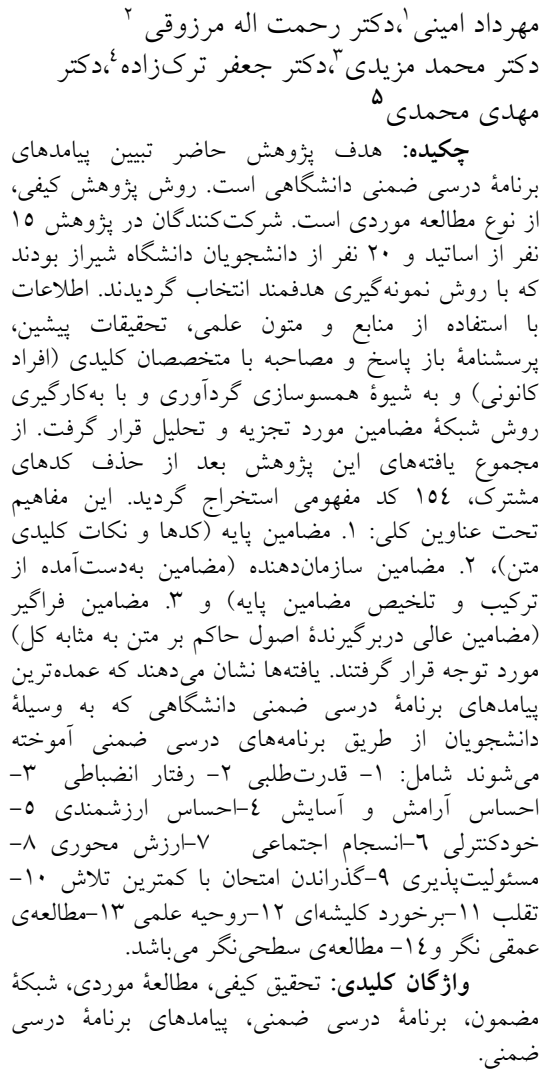

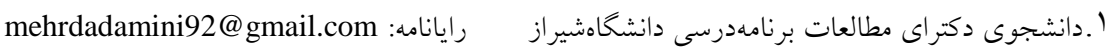

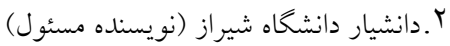

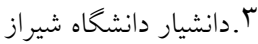

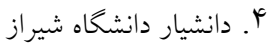

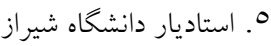

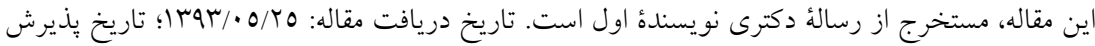

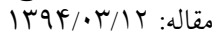




\section{مقدمه}

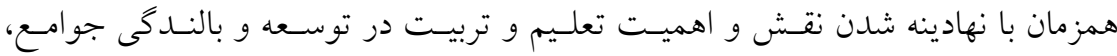

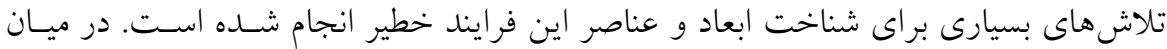

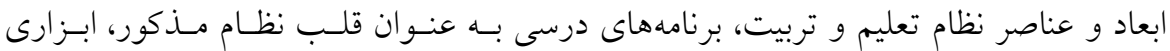

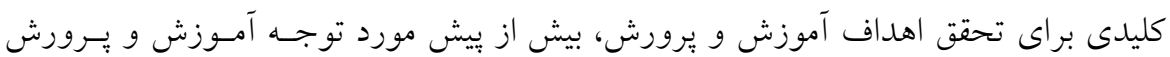

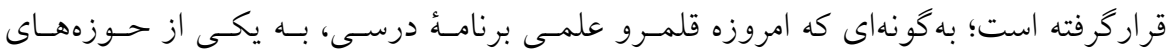

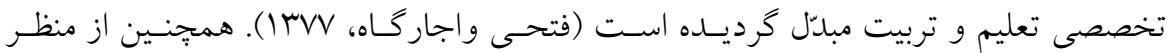

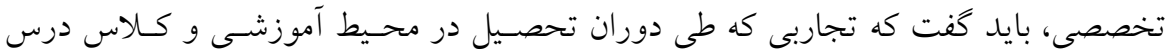

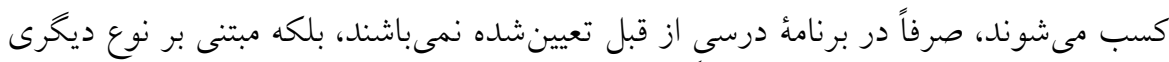

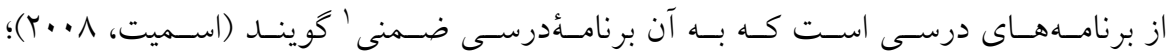

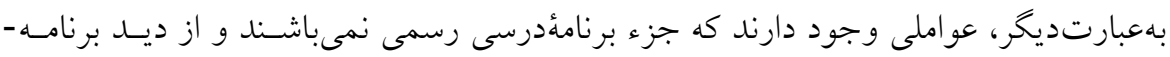

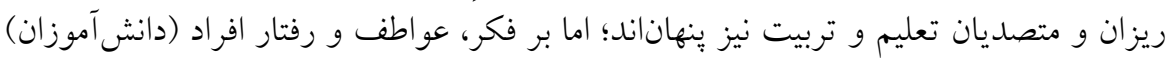

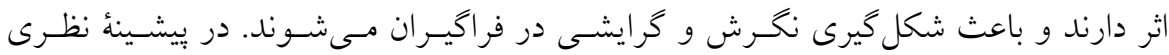

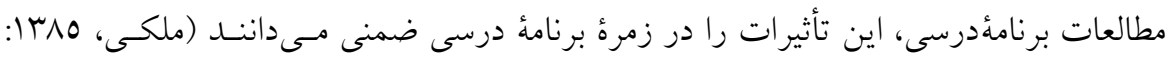

بهطوركلى برنامةدرسى در آموزش عالى داراى انواع و لايههاى متعـددى اسـت كـهـ

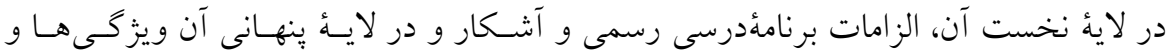

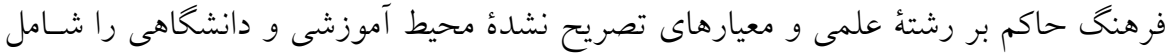

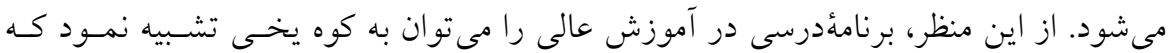

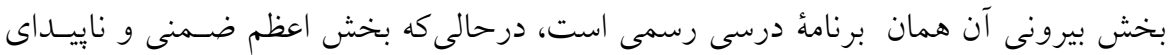

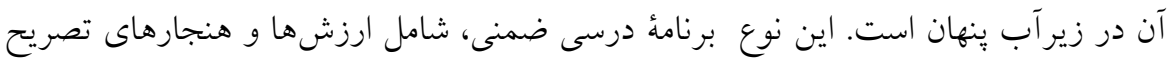

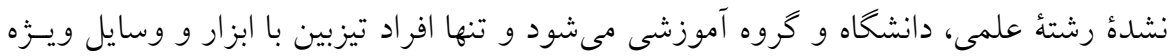

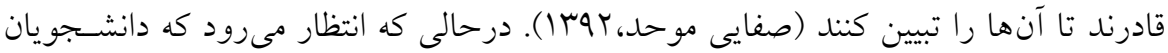

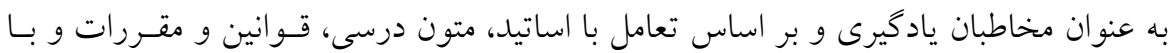

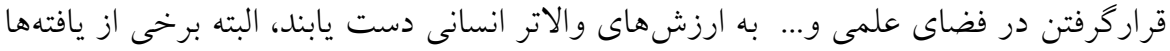

1. Implicit curriculum 


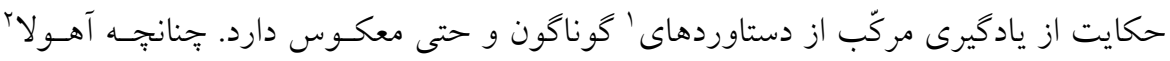

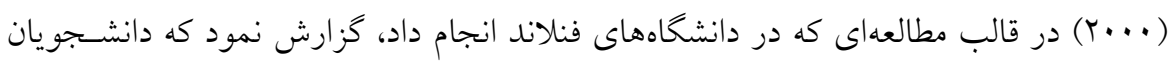

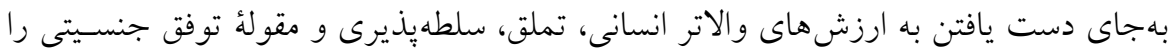
ياد مى كيرند.

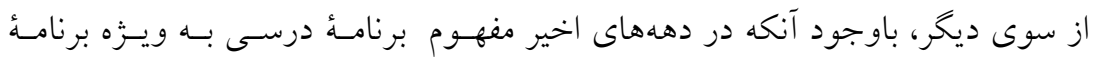

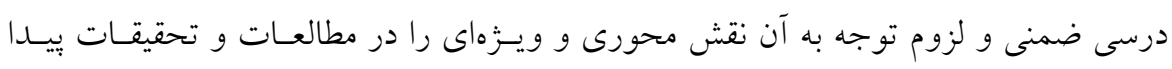

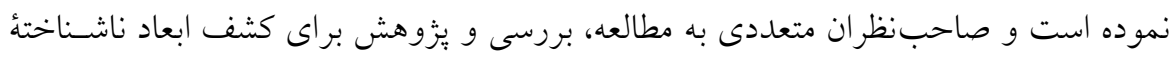

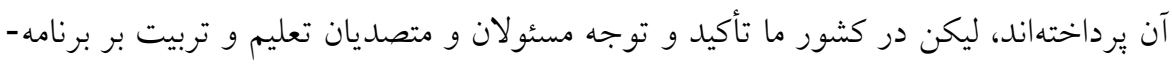

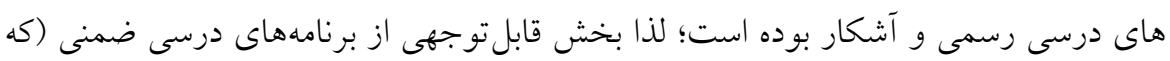

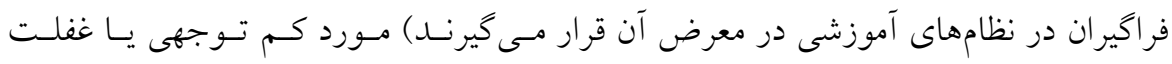

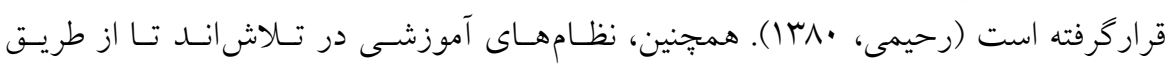

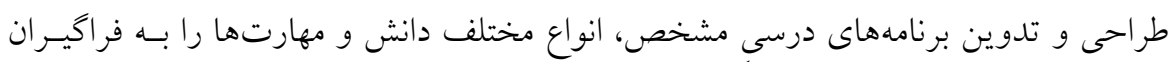

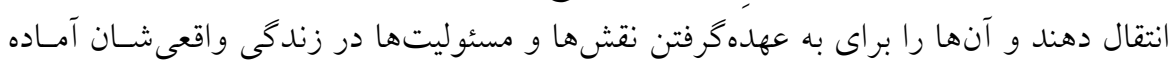

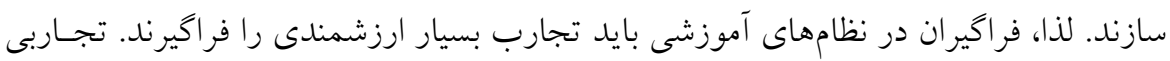

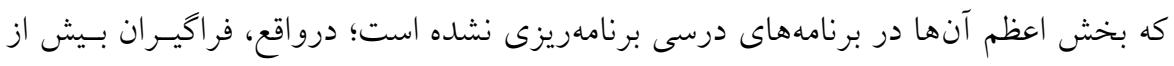

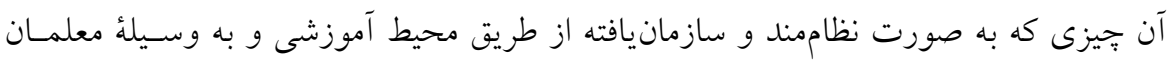

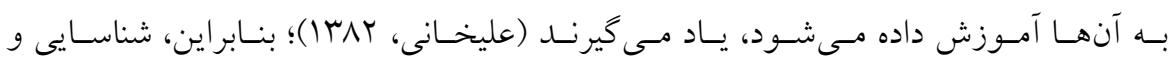

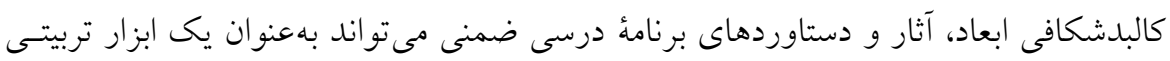

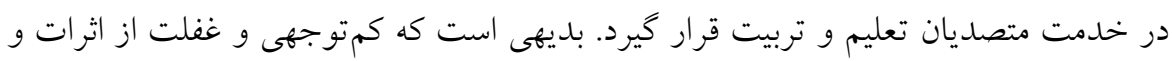

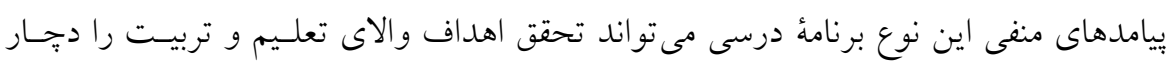

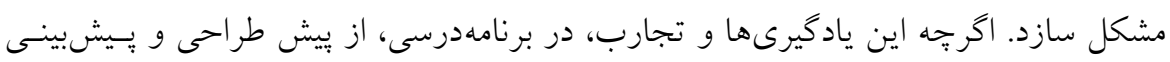

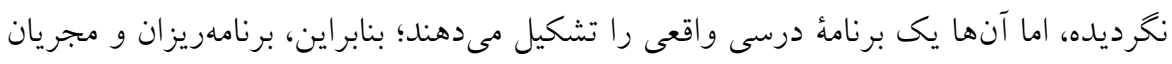

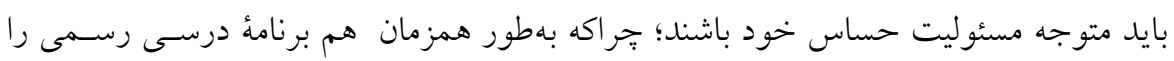

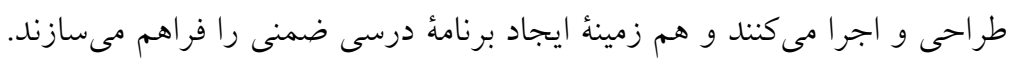

1 -Outcomes

2 -Ahola 


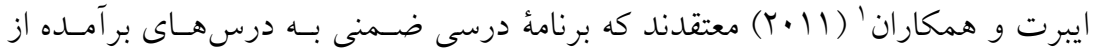
فرهنگ مدرسه و رفتارها، نخرشها و انتظاراتى كه از سوى آن فرهنخ مشخص شــده اسـت، اشاره دارد. بهعنو انمثال، هرجيند كه تربيت يك شهروند خوب ممكن است بهعنوان بخشى از برنامههاى درسى صريح و رسمى مدرسه در نظر گرفتهشده باشد، اما عادات و رسوم خاصسى كه مروّج مواردى از قبيل يذّيرش جند قوميتى و همكارى بين دانش آموزان است نيز مى توانــ

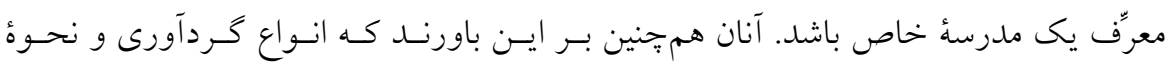

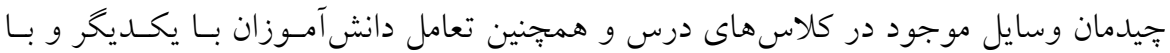
معلم در كلاس درس مىتواند برنامهُ درسى ضمنى مرتبط با ارزشهاى مورد نظـر مدرسـه را

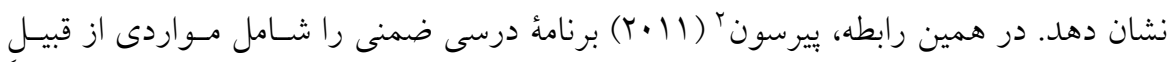

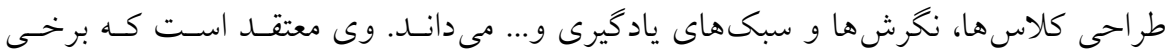
برنامههاى درسى ضمنى از طريق ارائه و برخى نيز با عدم ارائه تدريس مىشوند.

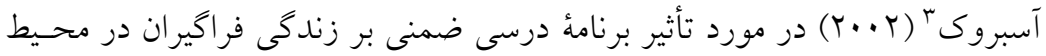

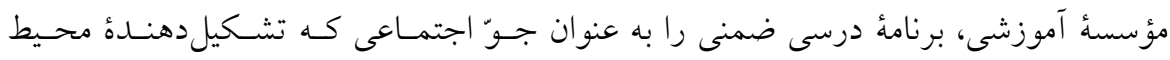

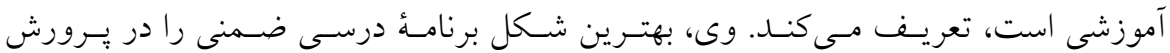
كنجكاوى عقلانى و رشد عاطفى خلاصه نموده است كه فرصتهايى را براى اكتشاف علايت نوين و توسعه توانايىهاى جديد فراهم مى آورد. در نقطهُ مقابل و در بــدترين حالـت، برنامـــ درسى ضمنى مى تواند باعث تضعيف تفكر انتقادى و ارسال بيـامهـاى منفسى در زمينـهُ رشـــ عقلانى و منطقى شود. مواردى همجيجون ايجاد تقويت روحيةٌ رقابت بهجاى رفاقت، همكـارى و تشريك مساعى در سائ نظام ارزشيابى حاكم بر محيط آموزشى، ايجـاد و تقويست روحيـهُ

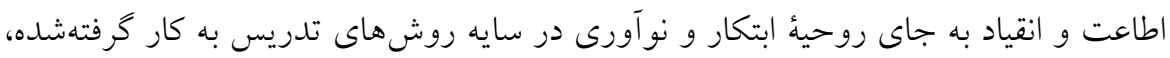

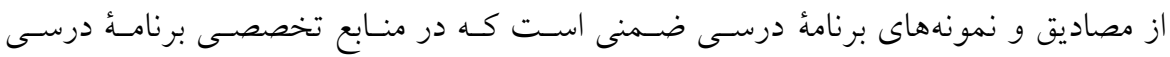

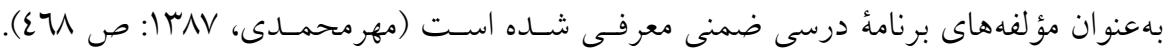
يزووهش هايى در اين حوزه انجام كرفته كه به تعدادى از آنها در جدول ( (1) اشاره مى گردد.

\footnotetext{
1 -Ebert et al

2 -Pearson

3 -Ausbrooks
} 
بررسى دستاوردها و ييامدهاى برنامهدرسى ضمنى...

جدول ا-برخى از تحقيقات انجامشده در حوزه برنامهُ درسى ضمنى

\begin{tabular}{|c|c|c|}
\hline نتايج & موضوع & محقق \\
\hline 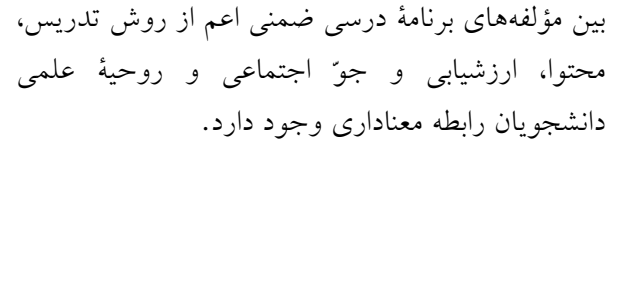 & مؤلفهدهاى برنامهٔ رابطة بين & 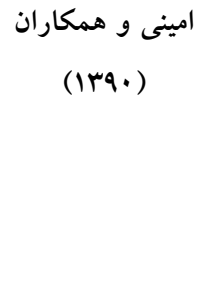 \\
\hline 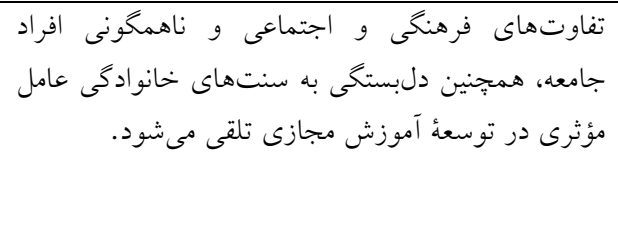 & 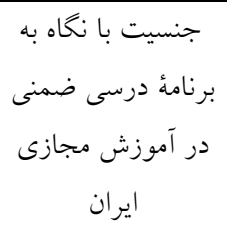 & هملى بور و \\
\hline دانشجويان تجارب منفى و مثبت متعددى در طول & 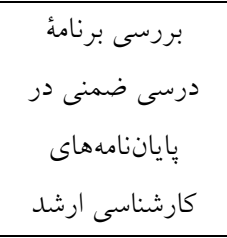 & فتحى واجارگاه و \\
\hline 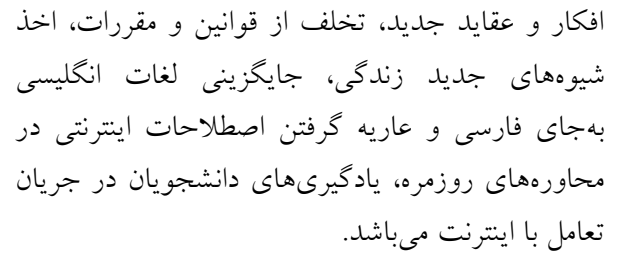 & 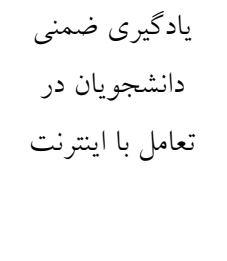 & كمثتى آراى و \\
\hline 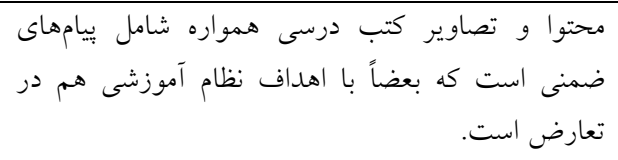 & 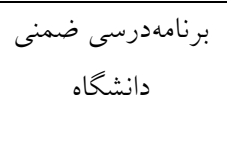 & $\begin{array}{l}\text { بر گهنخوين } \\
(Y+\cdots)\end{array}$ \\
\hline باعث ايجاد انفعال و سعتى و توجه آنها به دانشآموزان يسر، & جنسيت در تعليم و & 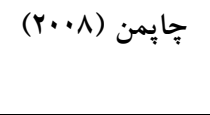 \\
\hline بى احترامى، خنديدن و سرزنش كردن بيماران & 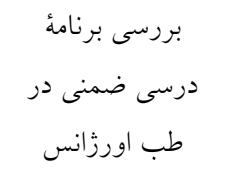 & لى بلانك (r..v) \\
\hline
\end{tabular}




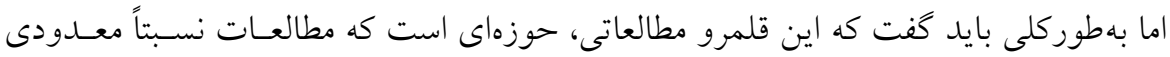

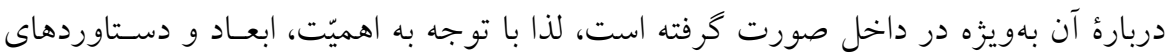

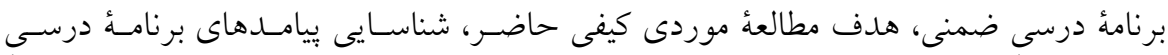

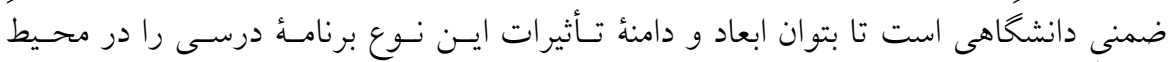

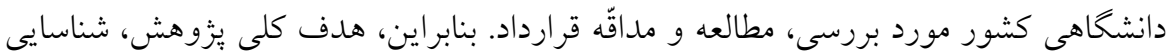

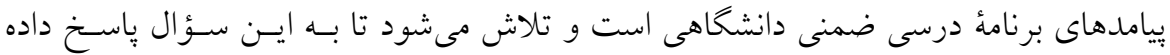

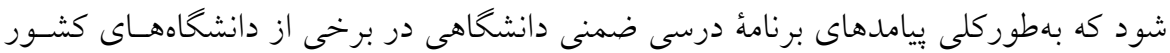

\section{روش شناسى يُزوهش}

يُزوهش حاضر از نوع كيفى و شيوه مطالعه موردى' است. مطالعهُ موردى كاوشى تجربى

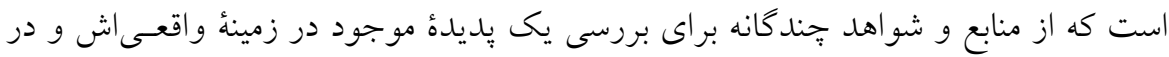

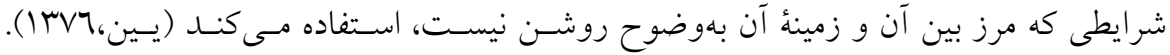

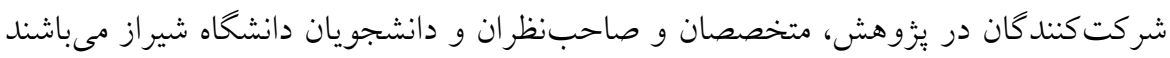

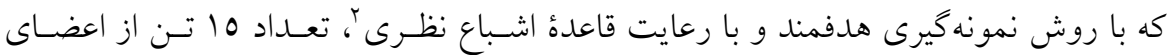

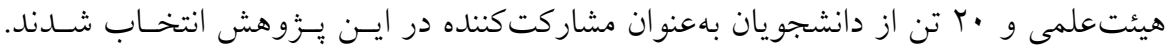

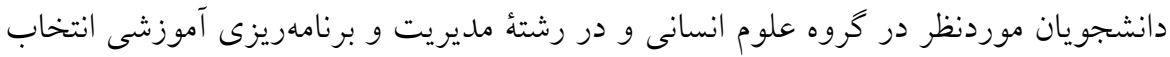

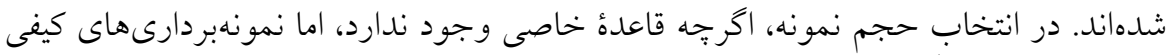

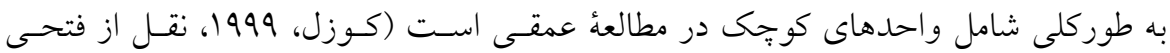

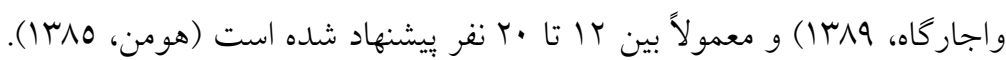

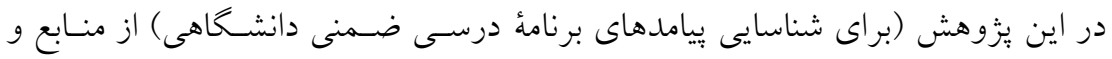

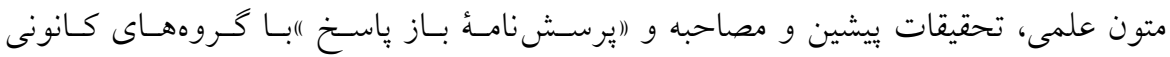

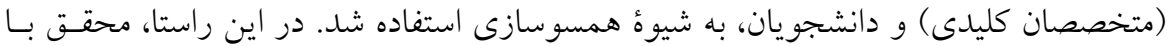

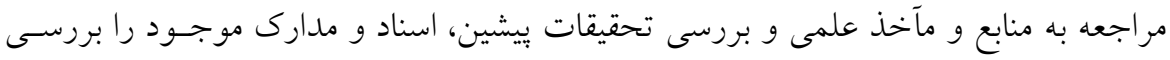

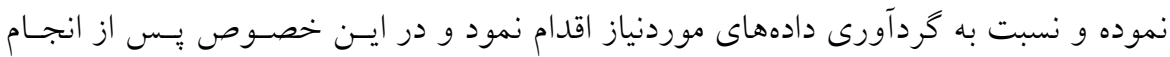

\footnotetext{
${ }^{1}$-Case study

2 -Theoretical saturation
} 
هماهنكى هاى لازم، مصاحبه كر براى مصاحبه در دفتر كار اساتيد دانشخاه شيراز حضور يافت

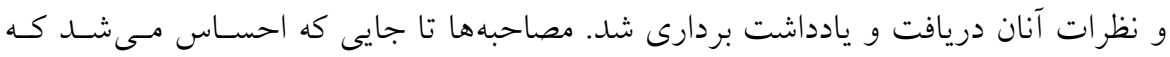

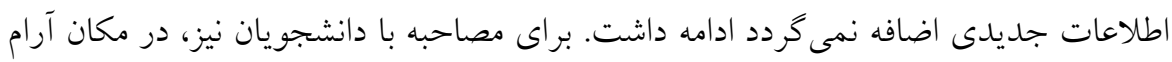

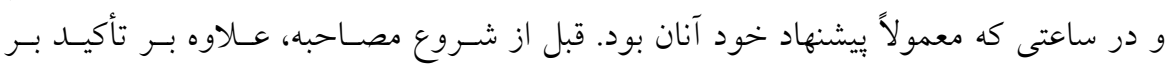

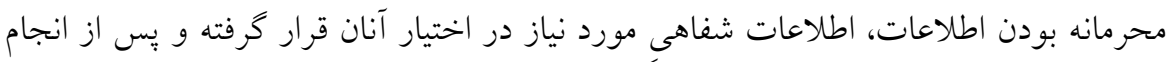

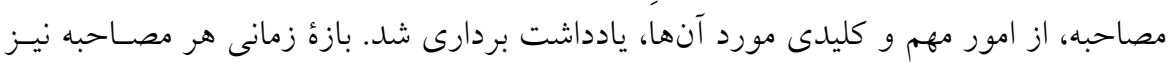

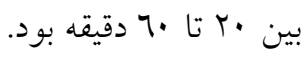

\section{روش تجزيه و تحليل دادهها}

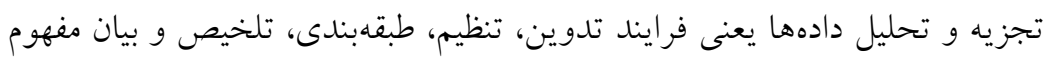

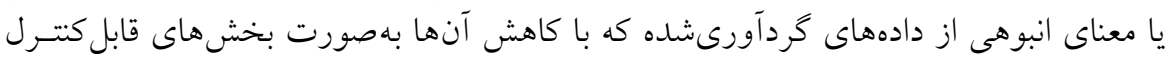

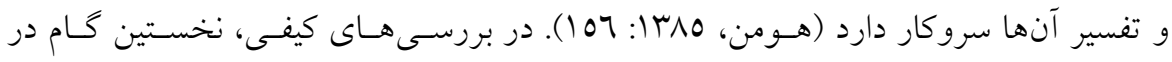

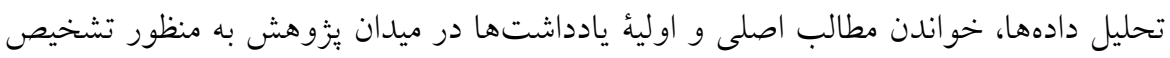

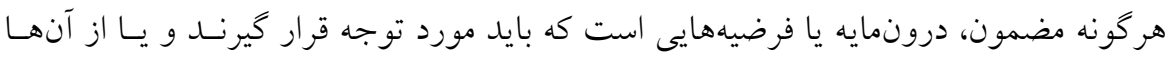

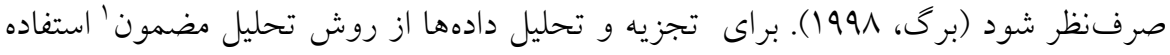

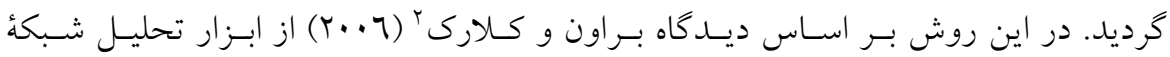

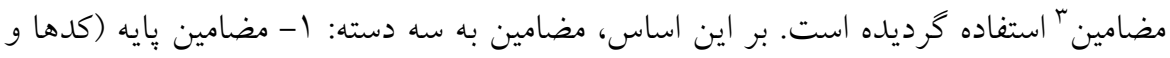

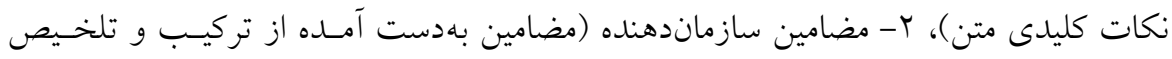

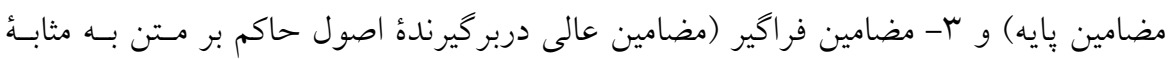

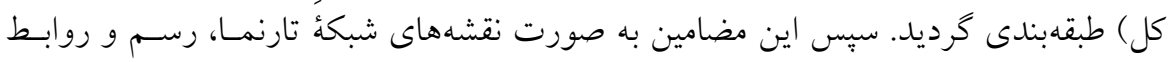

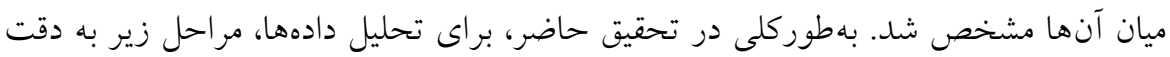
دنبال شده است: ا. مصاحبهها يك به يكى و كلمه به كلمه، بر روى كاغذ بياده كرديد.

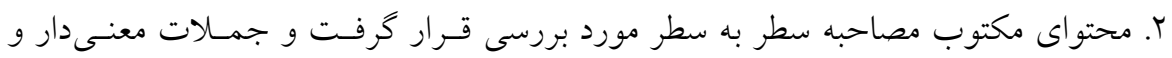

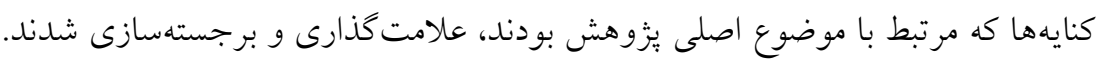

\footnotetext{
${ }^{1}$-Thematic Analysis

2 -Braun \& Clarke

3 -Thematic Network 
r. مطالب برجسته و حساس در دست نوشتهاى اسـاتيد و دانشـجويان از (يرسـشنامــُ بـاز

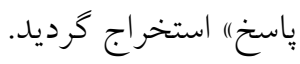

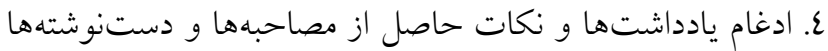

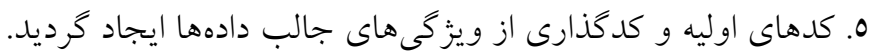

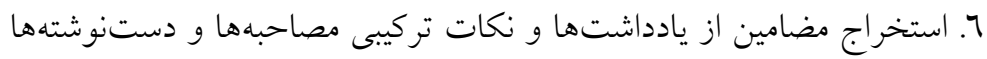

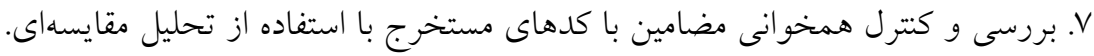

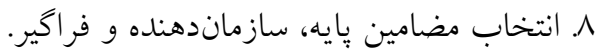
9. (. ترسيم شبكة مضامين. • ا. (1. تحليل شبكة مضامين.

\section{اعتبار سنجى كيفى دادهها}

در تحقيق حاضر، براى تعيين اعتبار درونى (قابليت اعتبار) يافتهها، علاوه بر اينكه دادهــا

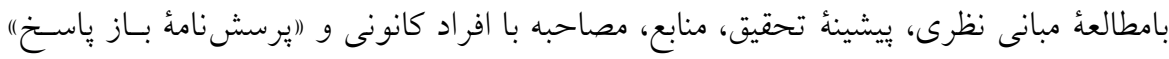

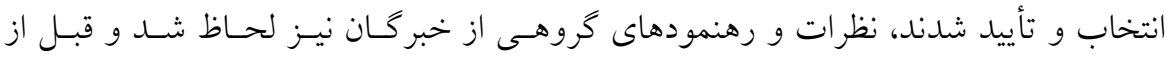

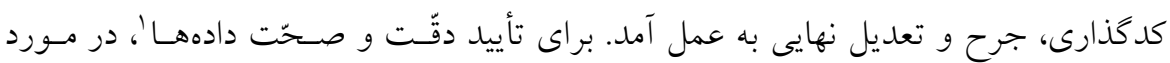

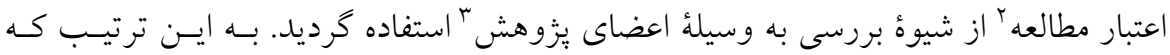

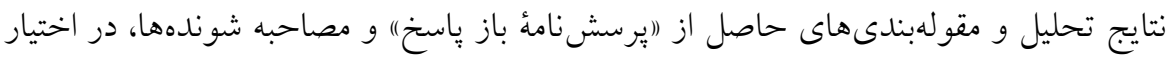

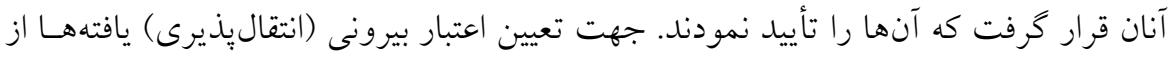

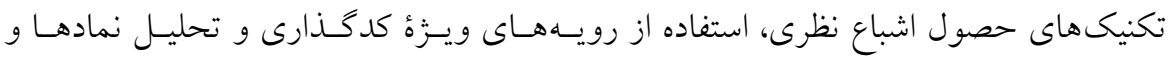

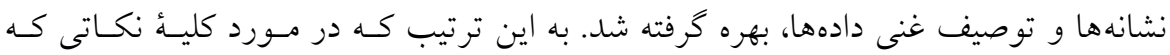

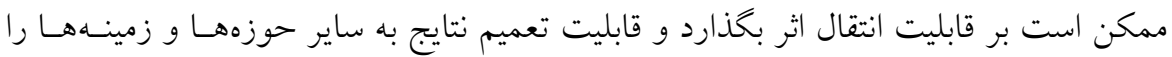

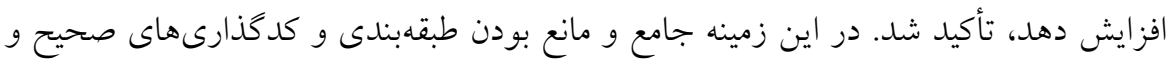

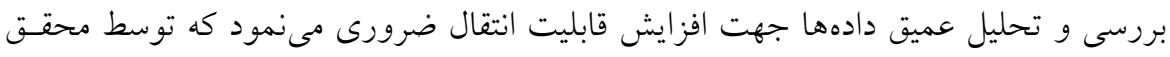

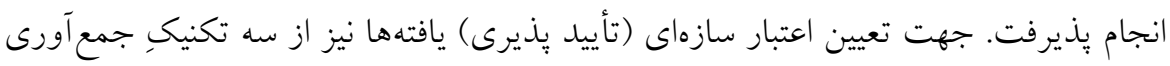

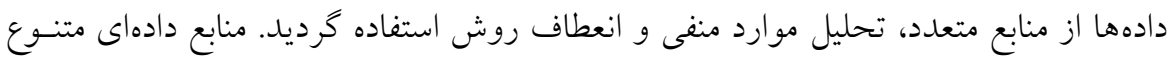

\footnotetext{
1 -Trustworthiness

2 -Credibility

${ }^{3}$-Member check
} 
بررسى دستاوردها و يِيامدهاى برنامهدرسى ضمنى...

بوده و همسوسازى بـ كار گرفتهشده است. محقق در تحليل موارد منفى مصاحبههـا، تبيينـات

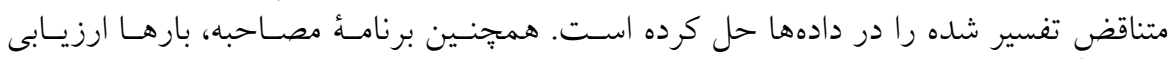

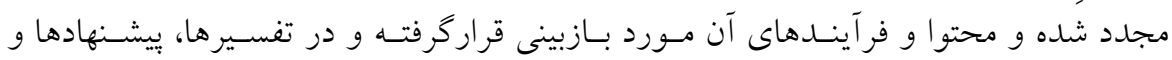

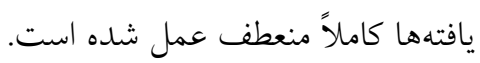

يافته ها

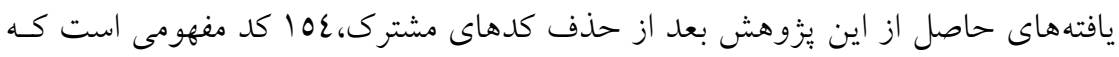
حاكى از يادكيرىهاى ضمنى دانشجويان در محيط دانشخاهى است. ايسن مفـاهيم تحست ســـ عنوان كلى مضامين بايه، سازماندهنده و فراگير به شرح زير انتخاب گرديد:

ا - مضامين يايه:

مضامين يايةٌ انتخاب شده از نكات كليدى سبا مضمون است كه اين مضامين در جـدول

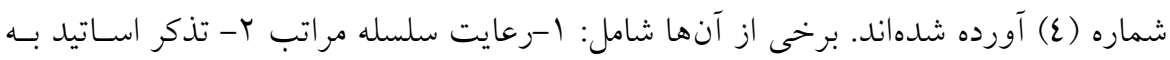
دانشجويان، تشويق ب- تنبيه ع- سيستم بِاداشدهى 0- امتحانات رسمى 1- شيوههاى مراقبت

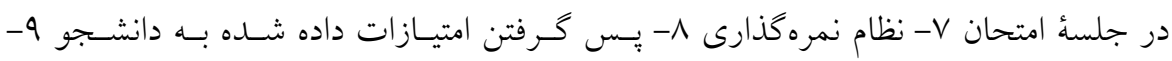
حضور و غياب · ا-مقررات نشستن در كلاس ||- ساعت بركزارى كلاس و نظاير ايسنهـا مى باشند.

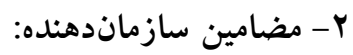

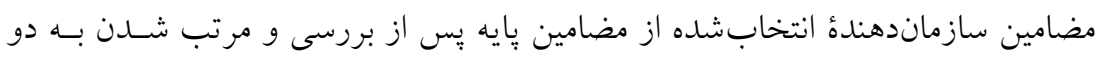

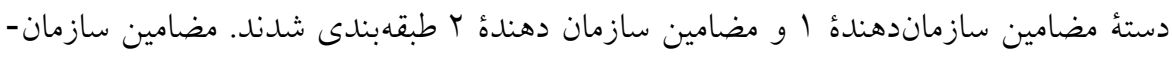
دهندة أشامل اين موارد مئباشند:

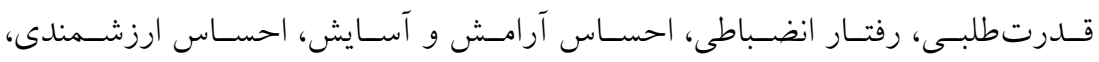

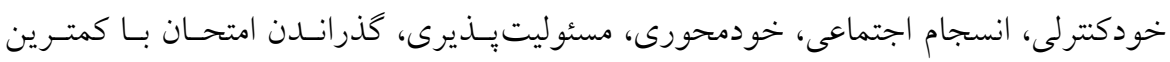

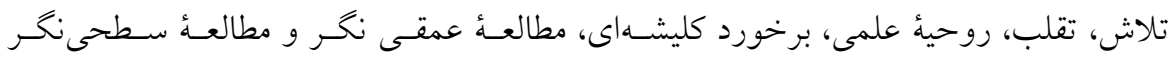

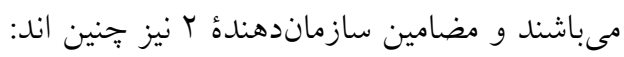

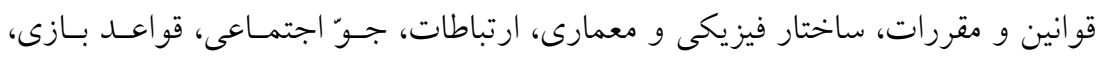
محتوا و باورهاى معرفت شناختى مى باشند. r- مضامين فراگير: 


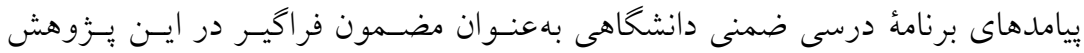
قلمداد مى گردد.

در جدول شماره (Y) مضامين فراخير، سازمان دهنده و كليدى (يايسه) بِيامــهاى برنامـــ درسى ضمنى دانشخاهى آورده شـده اسـت و در نمـودار ( (1) شـبكه مضـامين دسـتاوردها و ييامدهاى برنامة درسى ضمنى دانشخاهى آورده شده است. با توجه به كسترده بودن مضـامين

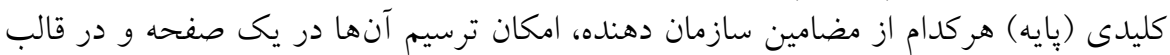
يكى نمودار وجود نداشت، لذا به منظـور نشـان دادن آنهـا در نمـودار كلى شــكئه مضـامين يّيامدها و دستاوردهاى برنامة درسى ضمنى، از اصطلاح ((مضامين كليدى مرتبط) استفاده شده

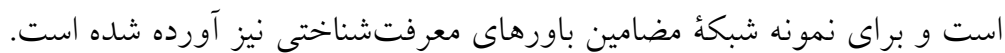

جدول شماره Y-مضامين فراگير، مضامين سازمان دهنده و مضامين بايه بيامدهاى برنامهٔ درسى ضمنى

\begin{tabular}{|c|c|c|c|c|}
\hline مضامين پايه (كليدى) & سازمان دهنامين & سازمان دهنده & فراخير & رديف \\
\hline 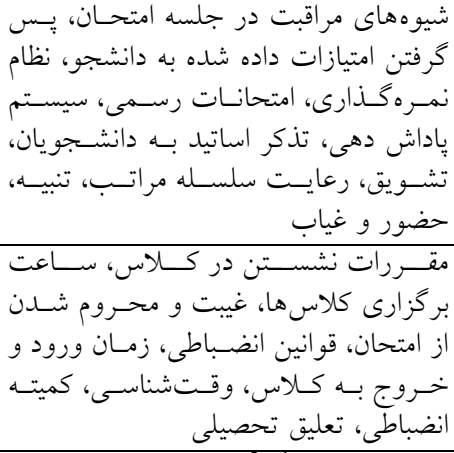 & رفتار انضباطى & ققورات و & بيامدهائ برنام & 1 \\
\hline 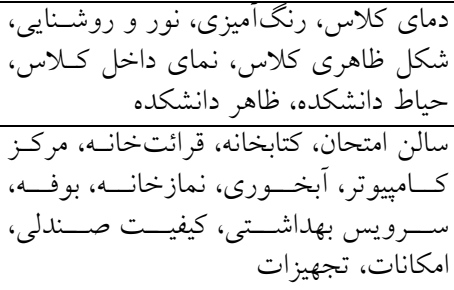 & و آساس آرامش & فيزيكى و & بيامدهائ & $r$ \\
\hline
\end{tabular}




\begin{tabular}{|c|c|c|c|c|}
\hline مضامين پايه (كليدى) & سازمان دهنده & سازمان دهند & فراكير & رديف \\
\hline 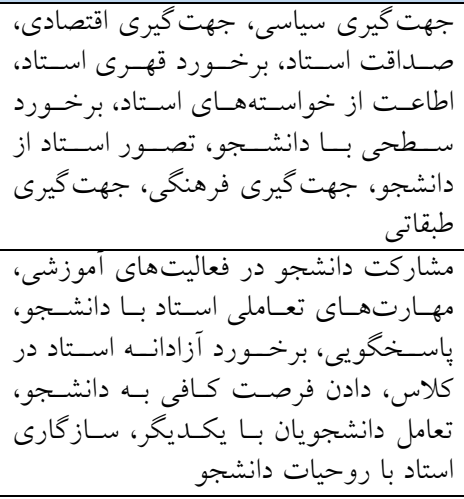 & جام اجتماعى & ارتباطات & بيامدهائ & $r$ \\
\hline 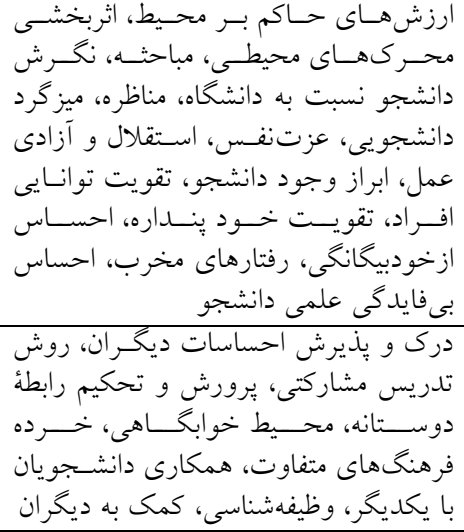 & مسئوليت يذيرى & جو اجتماعى & بيامدهائ & $\varepsilon$ \\
\hline 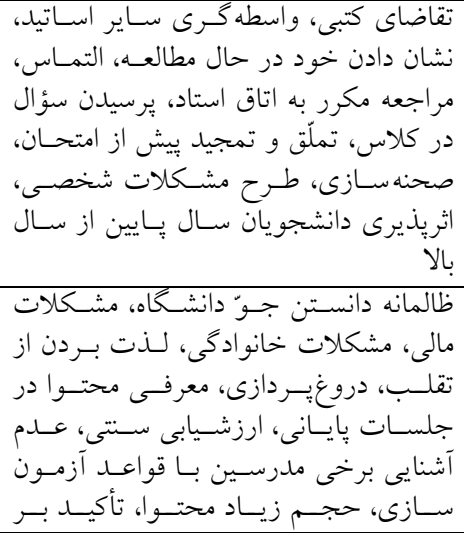 & 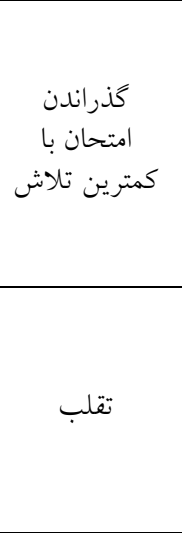 & قو اعد بازى & بيامدهائ & 0 \\
\hline
\end{tabular}




\begin{tabular}{|c|c|c|c|c|}
\hline مضامين پايه (كليدى) & سازمان دهنده & سازمان دهنده & فراخير & رديف \\
\hline جزئيات، سندسازى & & & & \\
\hline 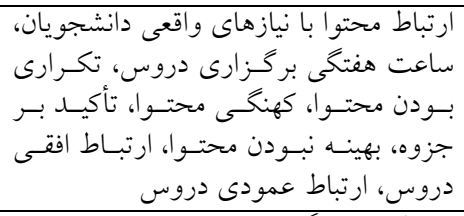 & روحيه علمى & \multirow[b]{2}{*}{ محتو ا } & \multirow{2}{*}{ 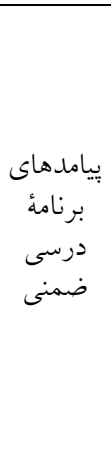 } & \multirow[b]{2}{*}{7} \\
\hline 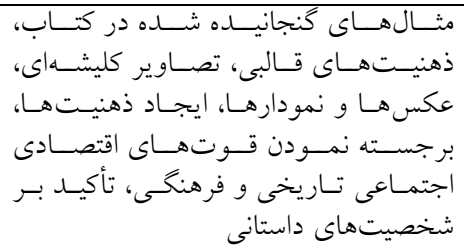 & كليشهاى & & & \\
\hline 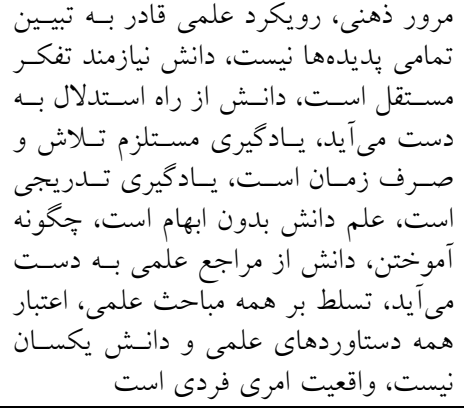 & مطالعه عمقى & \multirow{2}{*}{ معرفتشناختى } & \multirow{2}{*}{ بر برنامهاى } & \multirow{2}{*}{ V } \\
\hline 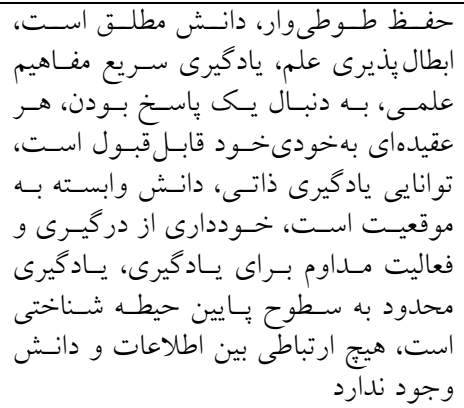 & سطحى نظخ & & & \\
\hline
\end{tabular}


بررسى دستاوردها و ييامدهاى برنامهدرسى ضمنى...

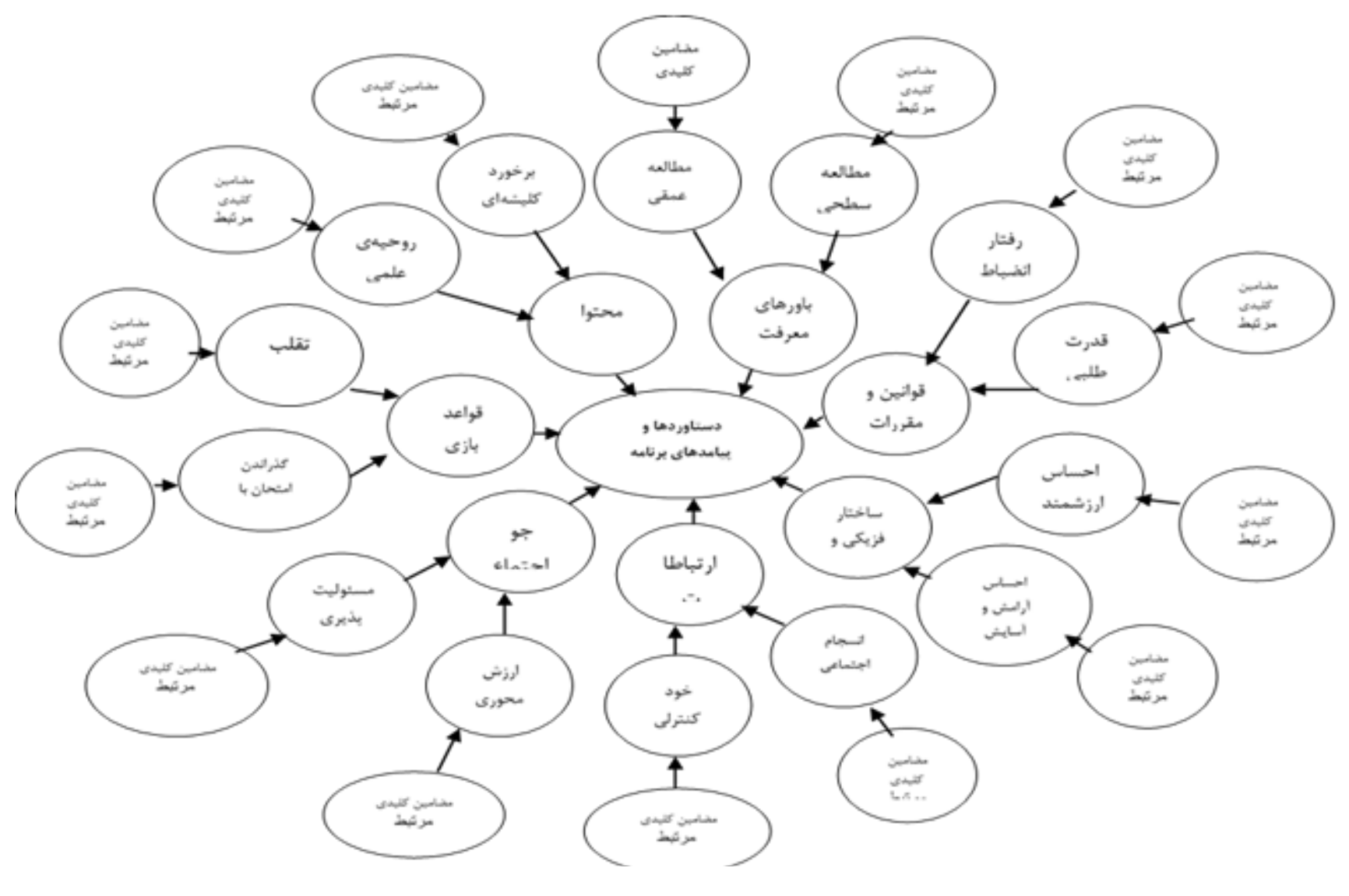




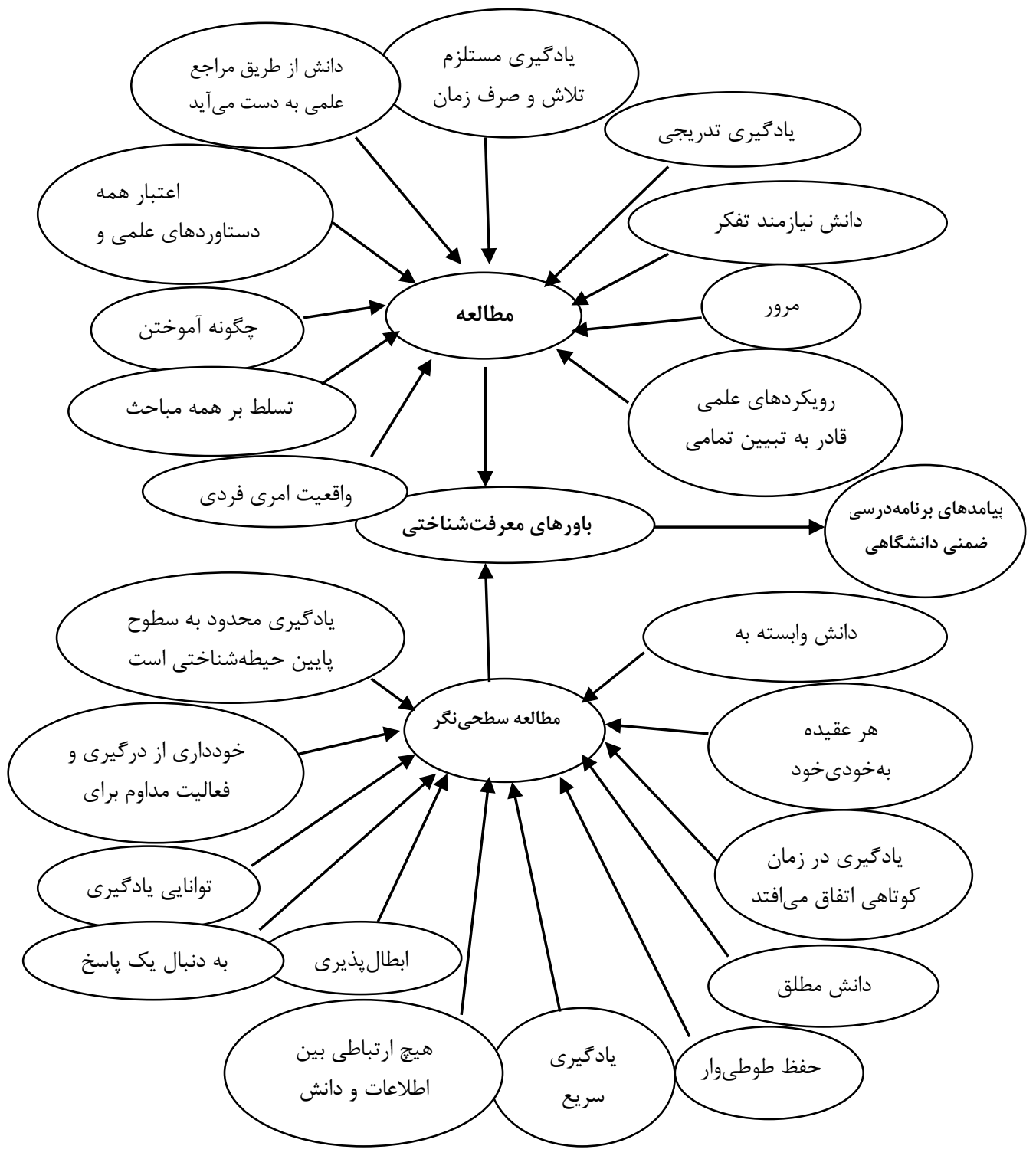

نمودار Y. شبكه مضامين باورهاى معرفتشناختى ناشى از برنامهُ درسى ضمنى دانشگاهى. 


\section{ييامدهاى برنامة درسى ضمنى دانشخاهى بر اساس تحليل مضمون}

بِ إز بررسى و تجزيه و تحليل شبكة مضامين، بيامدهاى برنامة درسى ضمنى دانشكاهى

$$
\text { در تحقيق حاضر به شرح زير است: }
$$

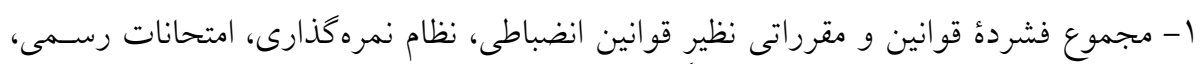

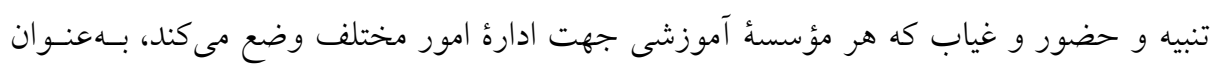

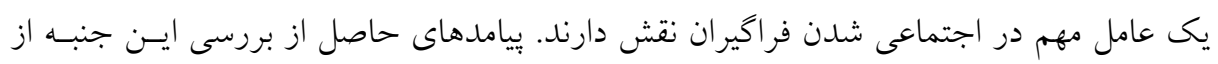

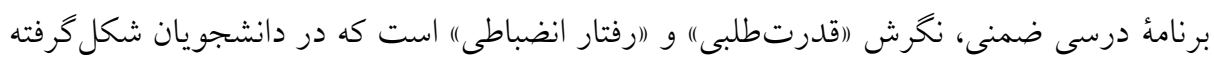
است.

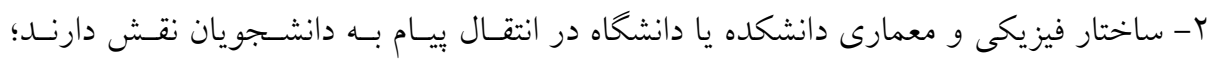

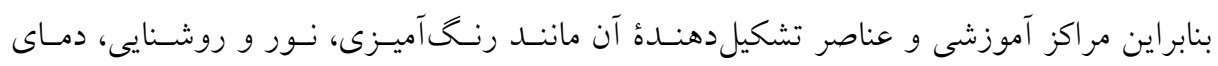

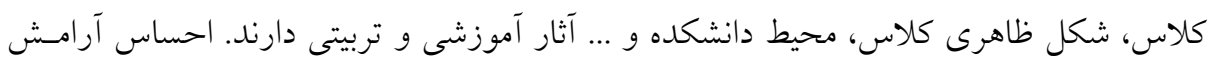

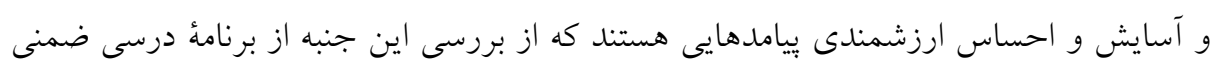
در اين بيزوهش محقق شد.

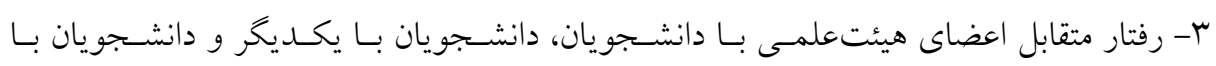

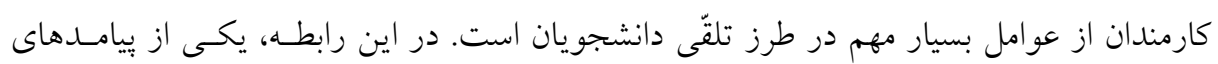

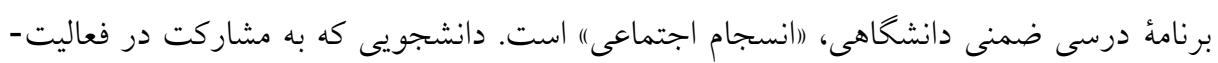

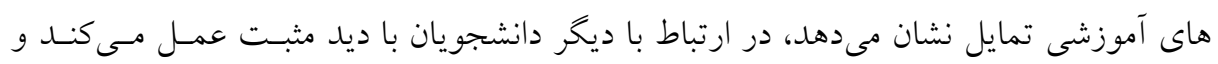

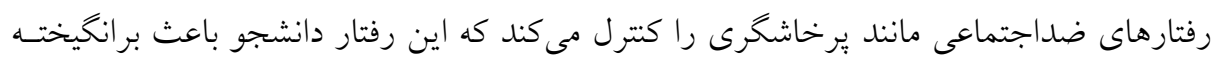

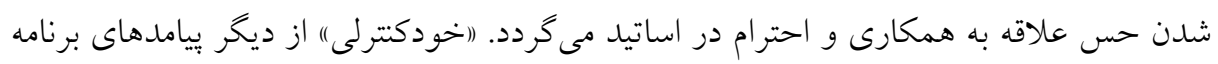
ضمنى دانشخاهى است كه محقق كرديد.

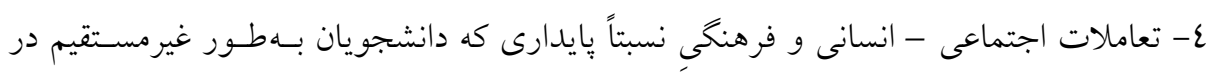

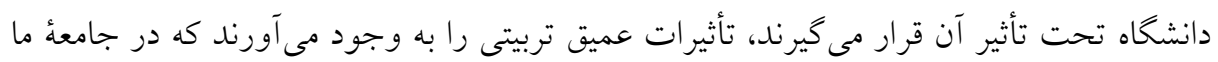

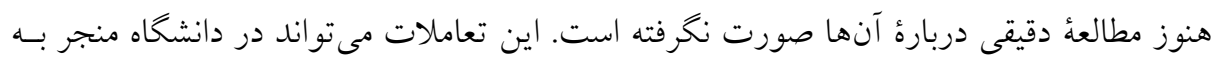

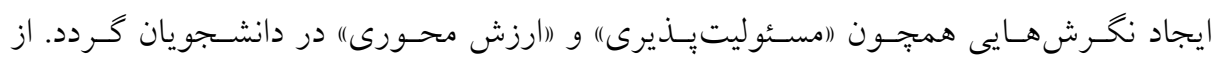

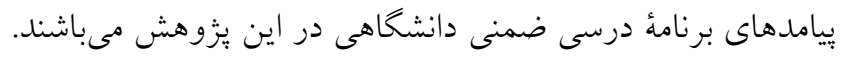


ه- ياد گيرى تملّق و خودنمايى و ضرورت توسّل به قواعد تأثير گذارى بر استادان نظير التمـاس،

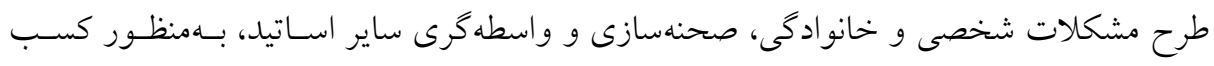

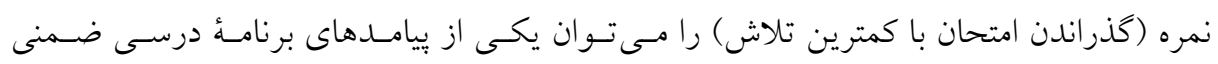

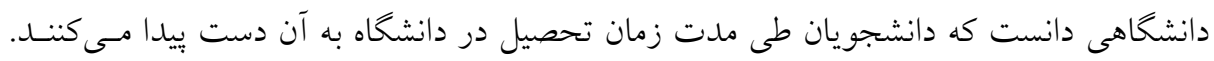

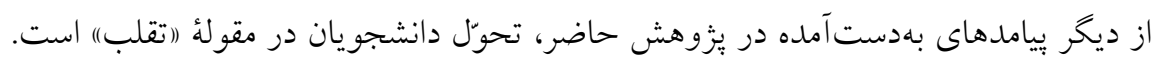

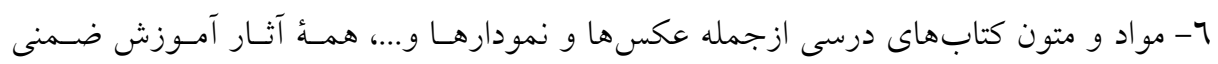

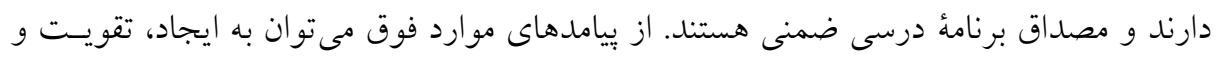

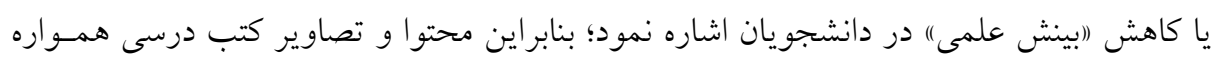

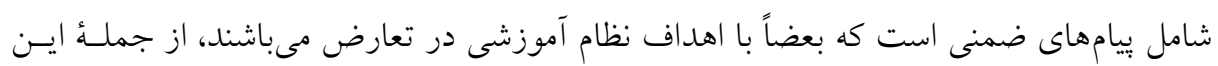

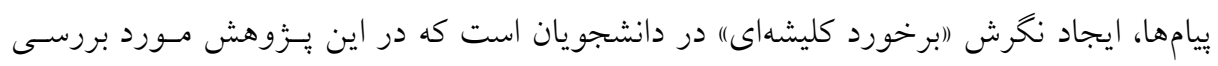
قرار كرفت. V- ازجمله آثار برنامة درسى ضمنى دانشخاهى، معانى و تفاسير مشتركى اسـت كـه دانشــويان

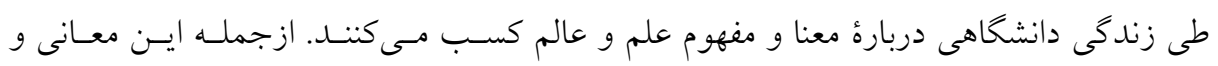

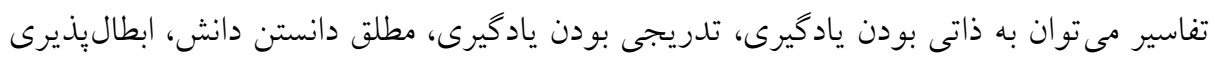

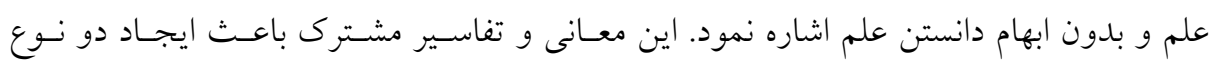

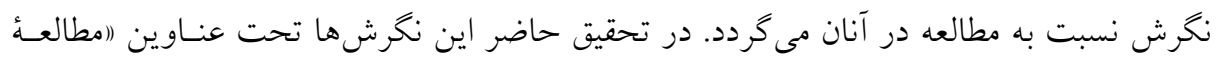

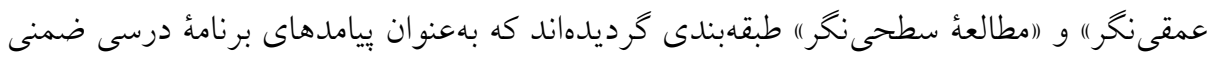
دانشخاهى قلمداد مى شوند.

\section{بحث و نتيجه گيرى}

يافتهاى تحقيق نشان داد دانشجويان تجارب مثبت و منفى متعددى در طول زمان تحصسيل

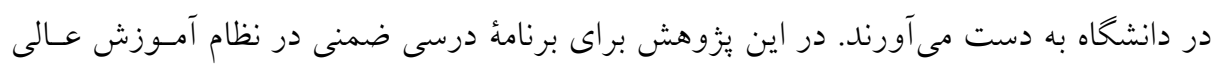

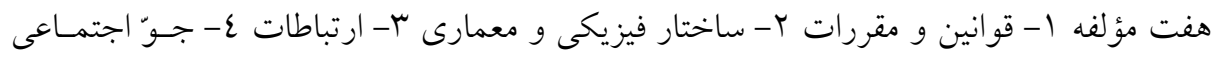

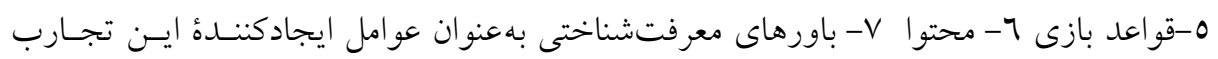

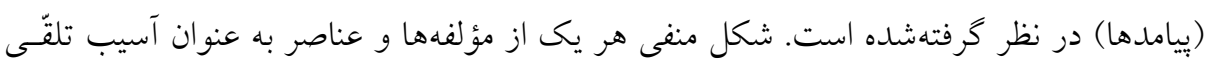


و به كسب تجارب ضد تربيتى منجر مىشود. يافتهها نشان داد كه هركدام از اين مؤلفـهــا مسى-

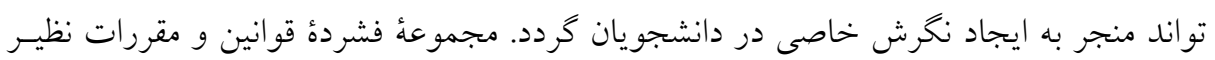

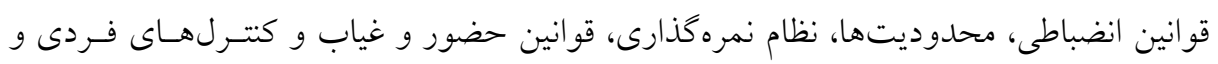

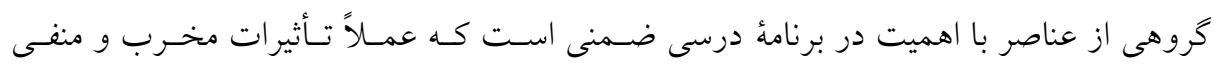

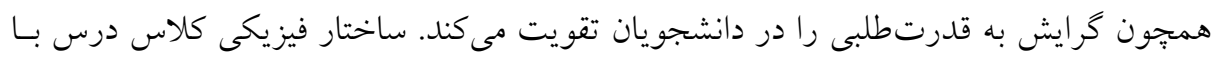

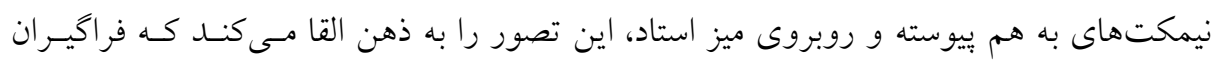
موجوداتى خالى از ذهن و تحت كنترل مدرسى هستند كه تنها منبـع يـادكيرى تلقـى مسى فئسوند.

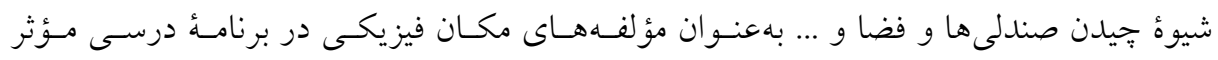

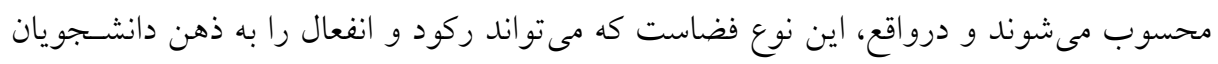

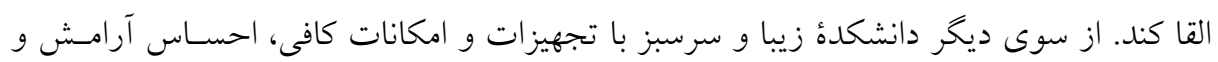

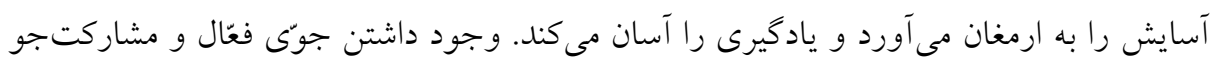

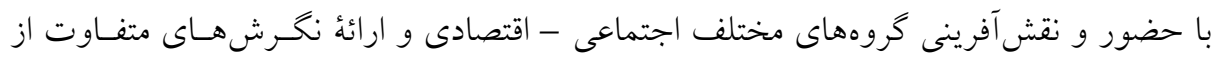

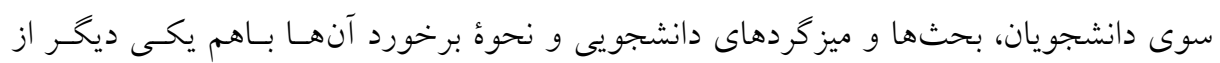

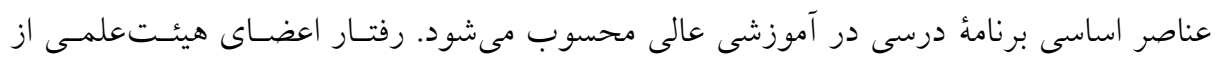

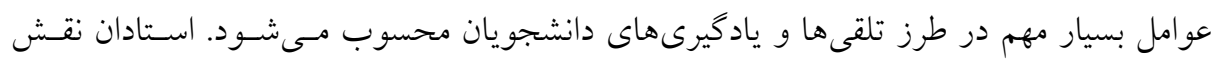

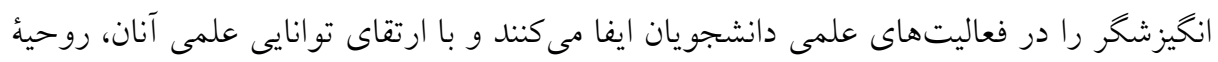

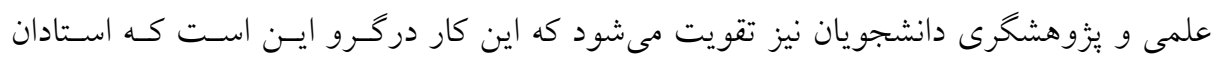
اطلاعات و دانش خود را همسو با نيازهاى دانشى و مهارتى دانشجويان روز آمد كنند و مهارت

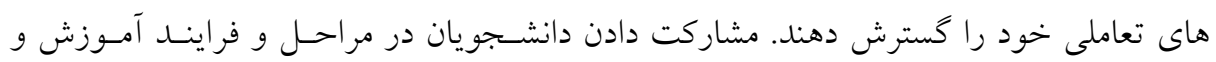

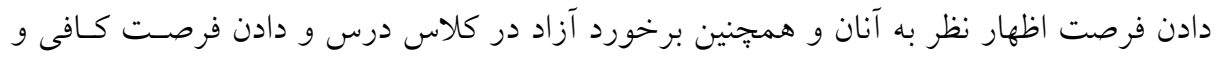

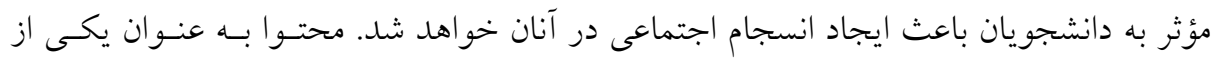

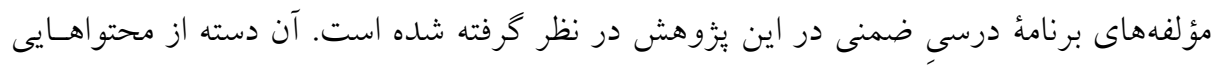

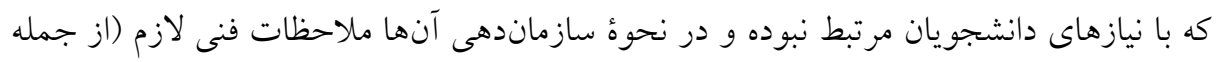

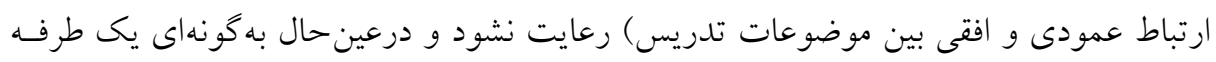

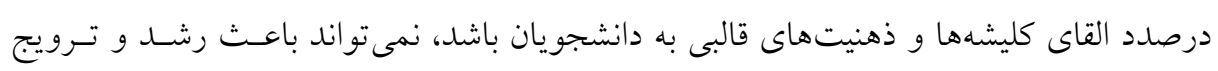

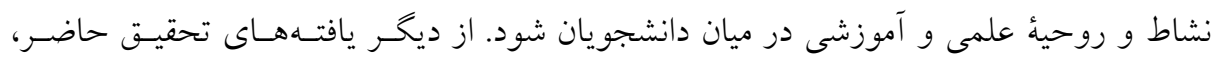


يادكيرى قواعد بازى و تحوّل دانشجويان در مقولهُ تقلب است. بايد عنايـت داشـت كـه هويـتـ

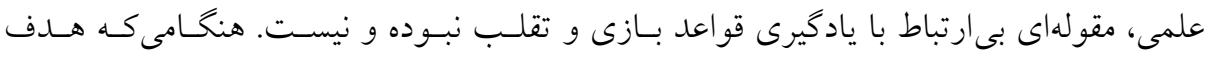

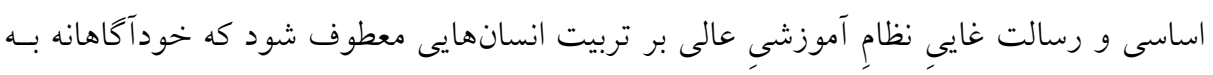

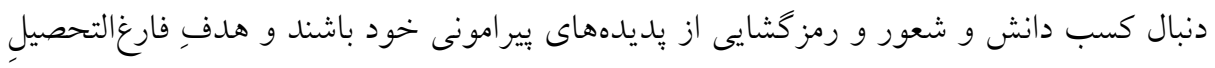

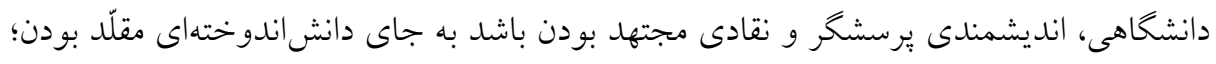

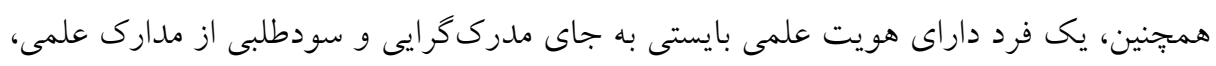

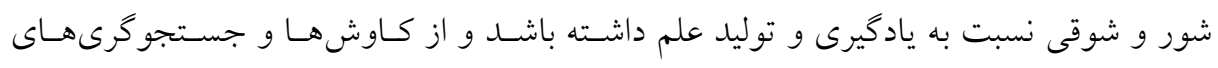

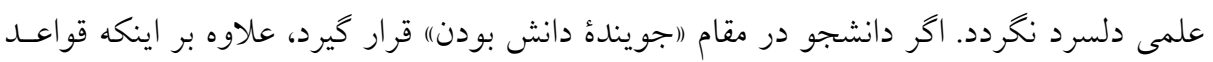

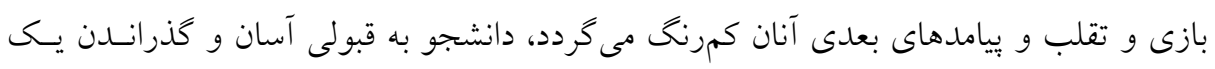

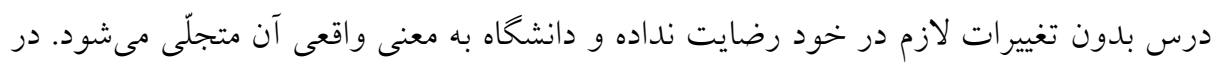

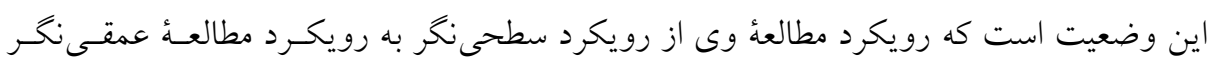
ارتقاء بيدا خواهد كرد. 


\section{منابع}

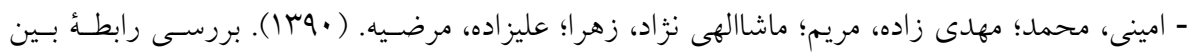

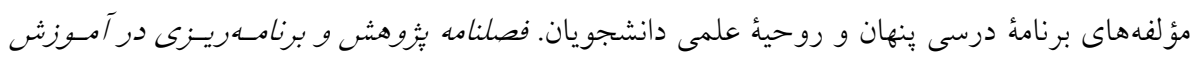

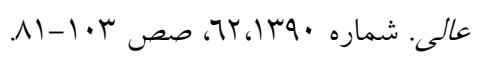

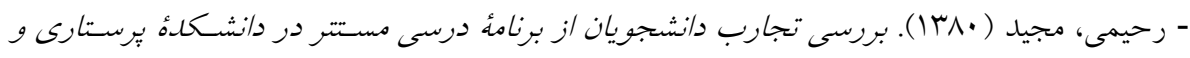

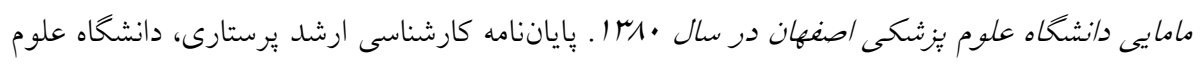
يزشكى اصفهان.

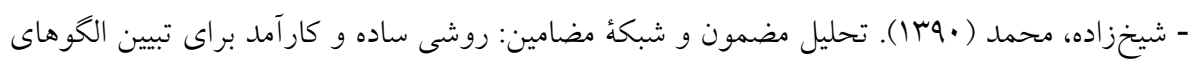

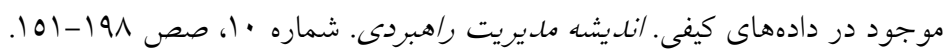

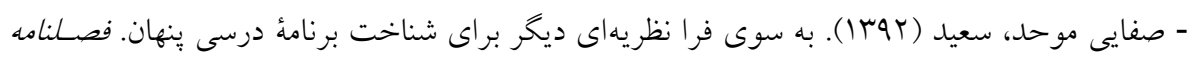

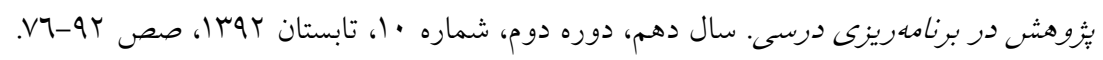

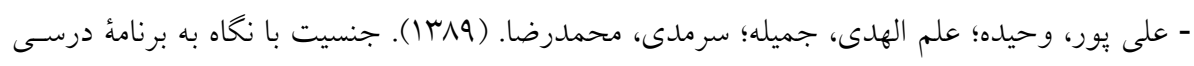

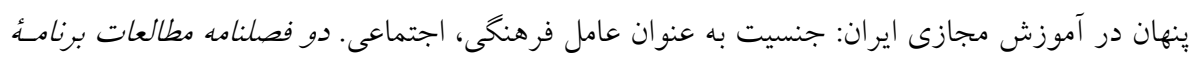

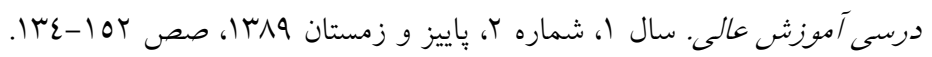

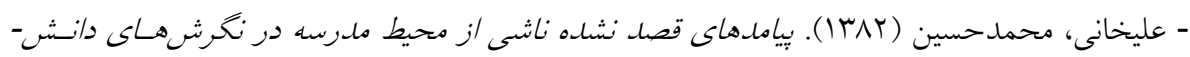

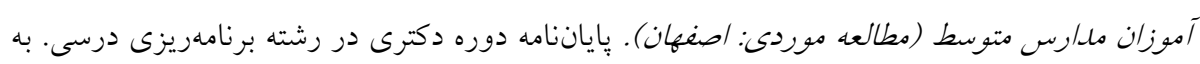
راهنمايى دكتر محمود مهرمحمدى، تهران: دانشخاه تربيت مدرس.

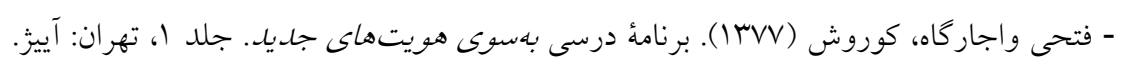

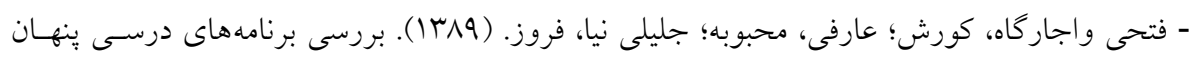

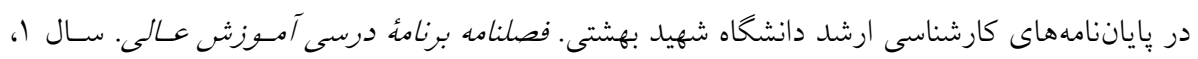

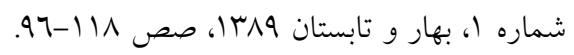

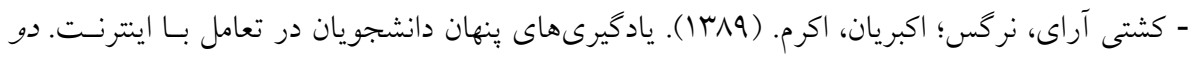

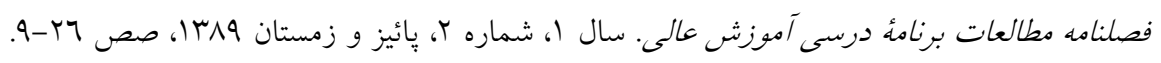

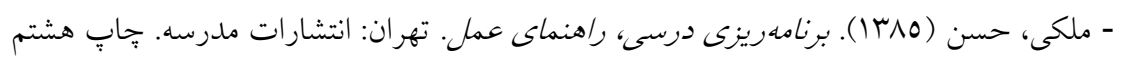

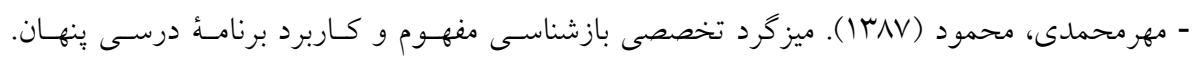

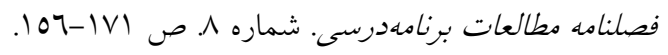




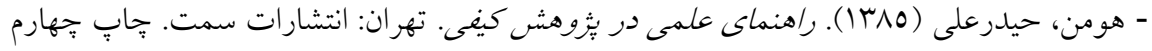

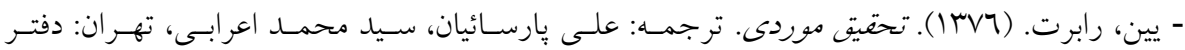

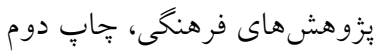

- Ahola, s. (2000). Hidden curriculum in higher education: something to fear for or comply to? Conference title: Innovations in higher education. Helsinki. 30/08/2000.

- Ausbrooks, R. (2002). What is the school's hidden curriculum teaching your child? Available from: http//www.parentingteens.com/ curriculum.shtml. 2002 [online].

- Bergenhengouwen, G. (2009). Hidden Curriculum in the University.Available at:http://www.sociologyindex.com.

- Braun, V. \& Clarke, V. (2006), "Using thematic analysis in psychology", Qualitative Research in psychology, vol. 3, No.2, pp. 77-101.

- Chapman, A. (2008).Gender Bias in Education. Available at: //www. Edchange. Org/ multicultural/paper/xbias.html.

- Connelly, F. M. Fang He M. phillion J. (2008). The sage handbook of curriculum and instruction. (1 st Ed.) Los Angeles: Sage publications.

- Delaney, L. Egan, M. (2011). The Experience of unemployment in Ireland: A thematic Analysis, Discussion Paper Series, Naval postgraduate School, Lieutenant, United States Navy.

- Ebert, e, II, Ebert, C (2011) the educator, s field guid: from organization to assessment. Thousand oaks. CA,: CORWIN

- Grady, M.D.Powers, Despard, M. \& Naylor, S. (2011).Measuring the implicit curriculum: initial development and results of an MSN survey.journal of social work education 47(3), 463-487.

- King, N. \& Horrocks, C. (2010). Interviews in qualitative research, London: Sage.

- LeBlanc, C. (2007). Exploring the hidden curriculum in Emergency medicine training program. M. A. Ed. Dissertation, Mount Saint Vincent University.

- Pearson, E.sh. (2011) Sunday school curriculum and the ministry of Christian edvcation, church publishing Incorporated.

- Smith, A. (2008). Values in Education in Northern Ireland chapter six; values and the Hidden curriculum CAIN web service.

- Tekian, A. (2009). Must the hidden curriculum be the black box for unspoken truth? Medical Education, 43, 522-523. 